ing commitment to Environmental Protection and Improvement. The award presentation ceremony for Dr Ripley will be held in Delhi some time during the forthcoming Science Congress in January 1986.
Desh Bandhu, President

Indian Environmental Society P.O. Box 7033

New Delhi 110002

India.

\title{
The Delhi Declaration on Environmental Education, 1985
}

We, the delegates to the Second International Conference on Environmental Education, held in New Delhi from 4-9 March 1985* under the auspices of the Indian Environmental Society and the Department of Environment, Government of India, and with the active support and participation of a number of governmental and nongovernmental agencies - including UN agencies and international organizations, as well as representatives of 35 countries - take into account the efforts made during the Stockholm Conference (1972), followed by the Belgrade Charter (1975), the Intergovernmental Conference at Tbilisi (1977), and the First Environmental Education Conference, New Delhi (1981), the International Workshop on Development and Biosphere Stability (New Delhi, 1984), and the Banff Declaration of the North American Association for Environmental Education Strategies (1984), further take note of the following:

(a) That, it is no longer possible to divide human experience into separate economic and ecological entities. Massive starvation in Africa, technological disasters in Mexico and Bhopal, and threats of increasing pollution, make it mandatory for us to recognize and integrate the environmental dimensions as a must for sustainable development;

(b) That, the need of the poor, the greed of the rich, and the careless application of technology, are the major causes of environmental degradation which need to be addressed in an integrated and holistic manner as pointed out by Mrs Indira Gandhi at the UN Conference on Human Environment (1972);

(c) That, the deliberations of this Conference, including the addresses delivered by the Vice-President of India and by the Minister of State for Environment, emphasized the need for environmental awareness as a prerequisite for action, and called upon individuals, groups, communities, national governments, and international bodies, to promote the cause of environmental conservation;

(d) That, environmental education and training should be an integral component of the educational process through formal and structured curricula as also through the non-formal media. This should aim at building professional manpower and an 'environmentally literate' and active citizenry;

(e) That, the majority of the population in developing countries is in the younger age-group, and a sizeable number of them still remain outside the purview of a formal educational system. The potential capabilities of youth, children, and womenfolk, as stressed by Mr Rajiv Gandhi time and again, should be introduced into the environmental conservation programme in the proposed revised Educational Policy. $\dagger$

Based on deliberations and consensus as arrived at by the Conference, we urge upon all concerned [the need] for immediate action on the following ten recommendations:

\footnotetext{
* On the very day on which this item goes to Press, we have received, from two leading participants, a formal article on that event which we hope it will be possible to restyle for the Conferences \& Meetings section of our next issue.-Ed.

$\dagger$ For India, and, let us hope and strongly advise, other nations throughout the world.-Ed.
}

(i) Environmental Education Associations at the national level should be established to serve the professional needs of environmental educators, to create linkages with governmental and nongovernmental agencies, and to assist in the development and dissemination of curriculum materials;

(ii) University teacher-training programmes should incorporate training in environmental education. Only when environmental education assumes a central place in all education will it begin to influence [large] scale management and governmental policy. Such training should include scientific and cultural studies related to human activities and the environment;

(iii) Each nation should consider establishment of a Youth Environment Corps consisting of youth (aged 16-22): the Corps would work on projects which promote ecologically sustainable development, especially in rural areas. Youth Corps projects should provide environmental knowledge and skills for participants in the programme;

(iv) Environmental Education Councils composed of local residents, officials, farmers, teachers, businessmen, and local bodies responsible for various environmentally-related projects and programmes, should be established at the local level. Such Councils would serve in an advisory capacity to assist in implementation of programmes at the local level;

(v) Environmental education demonstration projects should be established at the local level in concert with economic development projects to demonstrate the benefits of such a partnership. Such projects are necessary to gain local support for environmental education, and to provide working models for ecologically sustainable development;

(vi) Simple, easily applicable techniques should be developed for use by rural schoolteachers to demonstrate the practical importance of conserving Nature;

(vii) Environmental educators must develop practical pedagogical methods which address problems of environmental health in daily life-e.g. clean drinking-water, appropriate waste-disposal, and proper sanitation practices-as well as provide concepts and values regarding human-environment relationships;

(viii) Environmental Education curricula should be reviewed and, where appropriate, revised to provide inclusion of scientific and cultural (humanities, politics, economics) content sufficient to ensure that students understand the scientific basis of environment and ecology, and the organization and processes of human societies. Without this scientific and cultural understanding, students are unable to develop a useful holistic perspective for effective citizenship and professional life;

(ix) Universities, other educational, and research and development institutions, should be encouraged to generate new vistas of knowledge relating to environmental management in their respective areas of specialization; and

(x) The International Society For Environmental Education should establish a global Environmental Education communications system, to disseminate information and monitor indicators of The Biosphere's environmental quality-such as soil erosion, freshwater availability, food production, energy utilization, population growth, pollution loading, rates of deforestation, rates of desertification, and levels of soil salinization. 